\title{
ACCOUNTING ASPECTS OF AUDITING THE BUDGET SYSTEM
}

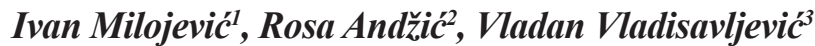

\begin{abstract}
Summary
Until recently the main instrument of state funding, the budget was only controlled by the existing system of a country's administrative control. Today there is budget audit as a special form of political control, which should contribute to a more appropriate and purposeful budget execution. It is still a condition sine qua non, i.e. an inevitable requirement for healthy public finances.
\end{abstract}

Key words: accounting, budget, audit, finance

JEL: H61, H83, Q19.

\section{Introduction}

Even though there is budget control, mistakes and irregularities in its execution are inevitable. It is for those reasons that budget audit exists. Budget audit is a state's instrument that permanently reminds its budget executors to work properly, in order to avoid irregularities and a need to find the accountable. This is why budget executors try to work regularly, in order to eliminate irregularities that perhaps even audit would not find, which decreases the inherent risk. In this way, budget audit is an addition to budget control and a guarantee of establishing budget discipline in public finances. Basic questions in budget audit from which its effect and efficiency depend are her assignment, scope and organization.

Budget audit has an assignment to question and determine whether budget executors complied with the procedure during the budget year, on questions of legality, rationality and usefulness. Two basic tasks of budget audit are securing proper budgeting i.e. budget execution according to budget regulations and securing finance for budget tasks with the goal to meet the country's interests at the highest level.

1 Ivan Milojević Ph.D., Full professor, University of Defense, Military Academy, Department of Finance, Pavla Jurišića Šturma street no. 33, Belgrade, Serbia, E-mail: drimilojevic@gmail.com,

2 Rosa Andžić Ph.D., Full professor, School of economics and management studies, Karađorđeva street no. 52, 34000 Kragujevac, Serbia, E-mail: rosa.andzic@vsem.edu.rs

3 Vladan Vladisavljević, Master of Economics, Asistent, University of Defense, Military Academy, Department of Finance, Pavla Jurišića Šturma street no. 33, Belgrade, Serbia, E-mail: vlada91@gmail.com

EP 2018 (65) 1 (337-348) 
In its work regarding legality, budget audit questions the work of budgetary accountants and managers. It states budgetary facts, compares them to the budget, questions their legality, and on its basis determines budgetary deviations determined and gives opinions.

The question of satisfying state interests relates only to managers who have discretionary right to use the budgetary funds. In this part budget audit questions whether budgeting was in accordance with state interests.

The scope of budget audit covers all budgetary operation, as well as all other work having to do with management of state assets related to the budget. In short, it can be systematized through the following: gathering i.e. payment of public revenue, execution of public expenditure and management of public assets.

Since the scope and missions of budget audit are very diverse and extensive, it is clear that its organization cannot be simple. Organization of budget audit shows significant differences in different countries and regions, but certain basic similarities exist. Many countries have built in laws on audit of the public sector within the provisions of the Lima declaration regarding the jurisdictions of budget audit and audit of public companies. For example, 24 member states of the EU have regulated in their laws on public sector that the Supreme Audit Institution (SAI) can audit the public sector.

\section{Literature review}

Since great part of public expenditure is financed by citizens, there is great interest in their purposeful use, and their unintended expenditure represents a harmful behavior. Republic of Serbia has perceived mechanisms for strengthening control of financial discipline in the public sector, such as fiscal rules anticipated by Law on budget system, which regulates the behavior of all users of public funds (Šuput, 2012).

State audit is one of the most important institutions, which conducts supervision of Budget expenditures (Filipova, 2015). Amongst the several control tools of risk management, internal audit is primarily used as an effective tool to manage operational, financial, legal and regulatory risks (Vijayakumar, Nagaraja, 2012). Achieving control on lawfulness of budget execution by independent audit institutions is an essential question for every country. Establishing an efficient system of external audit of budget expenditure is the best way in preventing state officials from unlawful expenditure of budget assets and one of the most important assumptions against successfully fighting crime (Lončar, 2012).

Each individual SAI has a different ,personality“ in the role that they aspire to when executing a performance audit. SAIs face strategic choices in further development of performance audits (Pollitt, 2003).

\section{Organization of state audit}

State audit and within it budget audit existed in many countries for hundreds of years and during their existence they changed their organization, way of functioning, jurisdictions etc. Today there are three basic models of organizing state audit through the SAI: 
- Judicial model, with judicial jurisdictions and authorizations;

- Judicial model without judicial jurisdictions and authorizations and

- With Head - Auditor General at the helm.

SAI is organized as a collegial body by a judicial model, with judicial jurisdictions and authorizations, also called the Napoleon's model. It is the oldest model of institutionally organizing SAIs that appeared at the beginning of the $19^{\text {th }}$ century in France (Bojić, 2009). SAIs that were organized in this way were a part of the judicial system of a country, which function as courts, auditors have the rights and obligations of judges in regular courts. In names of those SAIs, the word court is used as Court of auditors or Audit court. Today SAIs are organized in this way in France, Belgium, Luxemburg, Spain, Portugal, Italy, Greece and Romania. Considering that SAIs are organized as courts with judicial jurisdictions and authorizations, their work is primarily focused on compatibility audit.

Basic characteristics of SAIs organized according to this model are: accountants from Ministry of Finance are placed as head accountants in ministries and other institutions of the public sector, which gives more responsibility to the Ministry of Finance for the state in the public sector; head accountants are independent from the institutions of the public sector in which they are assigned; Ministry of Finance determines the regulations and rules based on which all head accountants act; audit court - court of auditors which implements a yearly audit of financial reports of all public sector institutions and all head accountants; court of auditors - audit court reports to the Parliament, Government and Ministry of Finance on conducted audits on a yearly basic.

SAIs organized as collegial bodies by a judicial model without court jurisdictions and authorizations are organizationally similar to courts, however not in the way they function. They are not a part of the judicial system and the reviewers do not have the rights and obligations of judges in regular courts. This model of SAI is the least prevalent type of this organization today and the institutions organized according to this model exist in Germany, Netherlands and the Czech Republic. The European Audit Court, the EU audit institution is organized and functions in this way. Basic features of SAIs organized in this way are: unlike SAIs who are headed by Auditor General, the function of Auditor General is performed by a collegial body - the board; all members of the board have the same status and all decisions are made by a consensus; other than the board there can be several Subcommittees and the Appeals Board which has the jurisdiction to arbitrate between Subcommittees; the principle of decision-making process through a consensus can be slow and difficult which calls into question the efficiency of the SAI.

SAI headed by Head - Auditor General is also called a parliamentary, monocratic or Anglo-Saxon model of organizing SAIs. This organization model is most widespread, i.e. most SAIs are organized in this way. Basic characteristic of this organization model and the difference from the other two is that the head of the audit institution is not the collegial body but a person, Head - Auditor General. Responsibilities, rights and obligations of the Auditor General are regulated by the constitution or a law that governs the matter of the public sector. This organization model is most consistent with 
the provisions of the Lima Declaration, which is to say that it exists and has the highest level of independence. SAIs organized in this way perform a financial audit within which audit of financial reports and performance audit is accentuated i.e. they perform a comprehensive audit of the public sector.

Basic features of SAIs based on this model are: the Parliament approves the budget for the Government and its institutions; Government and its institutions execute the budget and they deliver a report to the Parliament on its execution; Audit is performed by SAI; SAI delivers a report on the performed audit to the competent Parliamentary Committee i.e. Parliament that discusses it with the Government and SAI; The Government reports to the Parliament regarding the measures taken by the Parliament, Parliamentary Committee and SAI; all rights, authorizations and responsibilities regarding audit of the public sector are concentrated in the hands of the Auditor General. SAIs organized by model are in USA, England, Canada, Sweden, Denmark, Finland, Ireland, Austria, Hungary, Croatia and Estonia (Bojić, 2009).

It should be mentioned that until recently, another model of organizing budget audit existed and it does not exist today, SAI within the governing structure. Such model of organization existed in Sweden and Finland. Changing the constitution and laws that regulate the matter of the public sector in Finland in 2002 and in Sweden in 2003, SAIs are no longer within government structures, but within the Parliament and they are classified within the order of SAIs organized with Auditor General.

Laws that regulate audit of the public sector among other things regulate the jurisdictions of SAIs regarding which institutions within the public sector revise SAIs. There are very significant differences in jurisdictions of SAIs, from the possibility that they audit the central government and its institutions, whether they revise the central government, regional and city - municipality governments and institutions in their jurisdictions, to whether they revise other public bodes next to the aforementioned institutions and public sector. The following table shows the jurisdictions of certain SAIs.

Table 1. Organization of state audit in certain countries

\begin{tabular}{|l|l|l|l|l|l|}
\hline $\begin{array}{c}\text { Name of the } \\
\text { country }\end{array}$ & \multicolumn{1}{|c|}{$\begin{array}{c}\text { Central } \\
\text { government }\end{array}$} & $\begin{array}{c}\text { Regional } \\
\text { government }\end{array}$ & Municipalities & Public sector & $\begin{array}{c}\text { Other public } \\
\text { bodies }\end{array}$ \\
\hline Austria & $*$ & $*$ & $*$ & $*$ & $*$ \\
\hline Belgium & $*$ & $*$ & & $*$ & $*$ \\
\hline Denmark & $*$ & & & & $*$ \\
\hline Finland & $*$ & & & $*$ & $*$ \\
\hline France & $*$ & & & $*$ & $*$ \\
\hline Germany & $*$ & & & $*$ & $*$ \\
\hline Greece & $*$ & $*$ & $*$ & $*$ & $*$ \\
\hline Ireland & $*$ & & & & $*$ \\
\hline Italy & $*$ & $*$ & $*$ & $*$ & $*$ \\
\hline Luxemburg & $*$ & & & $*$ & $*$ \\
\hline
\end{tabular}




\begin{tabular}{|l|l|l|l|l|l|}
\hline Netherlands & $*$ & & & $*$ & $*$ \\
\hline Portugal & $*$ & $*$ & $*$ & $*$ & $*$ \\
\hline Spain & $*$ & $*$ & & $*$ & $*$ \\
\hline Sweden & $*$ & & & $*$ & $*$ \\
\hline Great Britain & $*$ & & & & $*$ \\
\hline
\end{tabular}

Source: Bojić, 2009

Jurisdictions of SAIs directly determine the number of clients they audit so for example NAO in Great Britain audits a few hundred clients per year and has 3000 clients it audits in the period of several years. Naming an Auditor General is differently regulated in different countries and there are three practices:

- Naming the Auditor General is under strict authority of the legislative authority, which is the case in Germany, Austria, Hungary, Croatia, Spain, Belgium, Sweden, Finland and Denmark;

- Naming the Auditor General is under the authority of executive authority which is the case in Portugal, Italy and Greece, and

- Naming the Auditor General is under the authority of legislative and executive authority, which is the case in Netherlands.

In certain countries, naming the Auditor General is significantly important and that is why the process includes the highest authorities of those countries such as the president in Ireland and the queen in Great Britain.

The length of the term is very different in different countries: four years in Portugal, six years in Sweden, eight years in Croatia, ten years in Spain, twelve years in Germany, Austria and Hungary, and a lifelong term in England and France, however the maximum age is limited to 68.

The way in which Auditor Generals are chosen and the length of their term are regulated by laws regarding audit of the public sector and directly influence the independence of the Auditor General and SAI, especially organizational and functional independence.

It is especially important for financial independence of the Auditor General and SAI that the budget of SAI is adopted only by Parliament and Parliamentary Committee for audit, whereas the Government - Ministry of Finance can be included. There are a couple of typical ways of adopting the budget of SAIs: in Denmark the budget of SAI is under the exclusive jurisdiction of the Parliament, after its proposal from SAI; in Finland the Parliament adopts the budget of SAI which as an integral part of the Parliament's budget; in Great Britain the budget is proposed by SAI to the Parliamentary Committee and the Parliamentary Committee proposes the budget to the Parliament which adopts it; in a number of countries (Germany, Austria, Spain, Portugal) the Government and Ministry of Finance have a significant role in the creation of SAI's budget.

From the above mentioned it is obvious that the organization of state and with it budget audit can be established as an individual institution of state audit institution or audit court, 
i.e. internal audit organization located either within each ministry or within the Ministry of Finance. Independence of audit institutions points to efficiency of audit and it is in direct correlation with the level of independency.

It is essential to create prerequisites for the work of budget audit, and the most important one is making and adopting the Annual Statement of Accounts (More available in Milojević, 2008).

Preparing the Annual Statement is required for control of all managers. In parliamentary organization, this is quite pronounced since Annual Statement of Accounts is made after the portfolio is released by the head manager. For example the examination of paying expenses and making revenue point to the work of accountants. On the other hand, purpose of issued orders points to the work of managers.

With that in mind, it is crucial to pass a law on responsibility of head managers, which should anticipate the civil responsibility for irregular budget execution (Andžić, 2013). This law would have its flaws in the form of hostility of capable individuals in accepting certain positions and prevention of executing certain very useful state tasks.

\section{Tasks of budget audit}

Control of a budget's execution always leaves voids that should be filled in order to establish healthy public finance system. These voids are compensated by budget audit. It is oriented towards the elements that are not covered by budget control, and above all it relates to appropriate budget execution and in some cases legality of doing business.

Budget control partially examines lawfulness in procedures when issuing and revaluating an order by a manager or an accountant, but it does not question the purpose of such orders. Having that in mind, budget control will not hold the manager accountable if those orders are irrational. For a proper public finance system, the question of purposefulness and rationality is as important as lawfulness. This is the reason why void left by budget control should be compensated by budget audit.

On the other hand, budget control does not have full inherences to stop an execution of irregularly issued orders. For example, in cases when a manager thinks objections made by controllers are unfounded regarding the regularity of issued orders or that execution of an illegally issued order (irregular changes to budgetary expenses etc.) is useful for the country. These voids should be compensated by budget audit which should additionally question whether executing the budget is rational, i.e. whose interpretation of regulations is correct, the managers' or accountants'. Institutionalization of such observed audit started in Lima with the declaration on the IX congress INTOSAI ${ }^{4}$ in 1977. It is considered a primary document when auditing the public sector based on which all other documents relate to when auditing the public sector including audit standards (Gavrić, 2015) for the public sector.

4 The International Organization of Supreme Audit Institutions is an international organization, organized by supreme audit institutions. INTOSAI was founded on the first congress of INTOSAI held from 02-09.11.1953. in Havana (Cuba). 
The main goal of Lima declaration is establishing and maintaining independence of SAIs. SAIs cannot survive and function unless they establish independence. It points out the need for provisions on independence of SAI to be incorporated into the legislative on audit of the public sector.

The Lima declaration consists of seven parts: general provisions; independence of audit and auditors; relation of audit with the Parliament, Government and public administration; jurisdictions of SAIs; methods of audits, auditors and international exchange of experiences; reporting on an audit and auditing subjects. ${ }^{5}$

General provisions relate to the purpose of auditing the public sector and types of audits. When purpose of an audit is in question, an audit isn't a formal act, but an integral part of a regulatory system with a goal to discover deviations in relation to adopted standards and breaking the principles of legality, rationality, efficiency and effectiveness when managing financial and other assets, in order to enable taking corrective measures and make the responsible accountable in order to take steps in discovering and preventing such transgressions. When types of public sector audits are in question, the Lima declaration differentiates audits according to criteria of time when they are performed, institutional positioning and jurisdictions.

Regarding the way that an audit is implemented it can be ex-ante and ex-post audit (unlike private sector audits, which are always ex-post controls). Ex-ante audit represents an overview before presenting the situation, administrative and financial activities and ex-post audit is done after presenting the situation. Ex-ante audit has the advantage of being able to prevent harm, but an imperfection of giving auditors a great deal of work, and SAIs do not have sufficient resources to perform such work. An ex-post audit is not able to prevent harm but it can influence compensation for damages, prevent their repetition and initiate assessment of responsibility (Stanojević, et al., 2016). Every country determines whether SAIs will perform ex-ante audits through their regulations, while ex-post audits are a compulsory activity of SAIs.

According to institutional positioning, Lima declaration differentiates internal and external audits in the public sector. Internal audits are organized within the organizational structure of the Government and its institutions and external audits are organized outside the organizational structure of the Government and its agencies. External audits are organized as SAIs. Among other things external audits have a mandate to revise the work of internal audits.

According to jurisdictions and subjects of an audit, Lima declaration differentiates financial audits (audit of financial statement and legality of doing business) and performance audits. Historically and traditionally SAIs are oriented towards financial audits - compatibility of doing business, however perspectives for development of public sector audits point out that SAIs in the future will be oriented towards performance audits. Aims of audits in the public sector ${ }^{6}$ performed by SAIs are of equal importance however regulations can decide to which type of audit SAIs will dedicate greater attention and priority.

5 www.INTOSAI.org - Lima Declaration

6 Lawfulness, economy, efficiency and purposeful use of budget assets.

EP 2018 (65) 1 (337-348) 
Provisions on independence imply independence of SAIs and auditors. SAIs can fulfill their role only if they are independent from the institutions that they audit and from other influences. Even though it is difficult to achieve complete independence of SAIs, they are expected to have organizational, functional and financial independence.

Relations of SAIs with the Parliament are regulated by highest normative regulations of state entities. The relation of SAIs with Parliamentary Committee regarding audit is especially important. When the relation of SAIs and the Government and its institutions are in question, SAIs should be protected from the influence of the Government and its institutions.

Jurisdictions of SAIs are determined by normative regulations and imply determining the subject, area, method of an audit, unhindered access to objects, assets, files, documents, other data and information important for performing an audit and open reports on a performed audit.

Provisions on work methods, auditors and international cooperation imply that SAIs will conduct their audit in accordance with plans and programs of an audit and that they will determine audit methods, techniques and procedures freely and independently. It is recommended for SAIs to base their audit manuals on modern audit theories and international auditory practice while respecting international specificity in order to ensure professional, independent and unbiased approach to the audit process and quality work of auditors. Lima declaration points out the need for qualifications, motivation, education and moral integrity of auditors. When international cooperation is in question, it is recommended to exchange experiences and ideas within INTOSAI and regional organizations such as EUROSAI and certain forms of bilateral cooperation.

Provisions on reporting treat reports for the Parliament and the public. SAIs are authorized and obliged to report to the Parliament i.e. competent Parliamentary Committee on audit results. Reports submitted to the Parliament are public reports - public documents available to the public in a way and form as decided by normative regulations. Lima declaration states basic authorizations of SAIs, i.e. subject of an audit, which can be the budget on various levels, taxes, public contracts, audit of electronic data processing, audit of public companies, institutions with subventions and international organizations.

According to the aforementioned, the audit of the public sector performed by SAI relates to budget audit. Tasks of budget audit consist of the following:

- It should question, i.e. decide whether the orders are according to regulations, especially in cases when there is a dispute between managers and accountants,

- It should question whether the violation of regulations done by managers when giving orders (especially for budget overruns) was justified i.e. purposeful and useful for the country.

- It should determine whether issuing orders, even within the budget and full respect of regulations was purposeful and useful for state interests. 


\section{Scope and process of budget audit}

Considering the mentioned tasks of state audit, it includes the work of all managers and accountants in the public finance system but it is de facto directed at head managers and accountants. ${ }^{7}$ This is justified by the fact that lower managers perform their work according to the instructions and control of head managers, which also relates to accountants in cases of their rights in repeated orders. This indicates that control of head managers' work includes the work of lower managers.

As a supreme legislative body, which controls the work within a country, the Parliament relies on the report of budget audit and based on it, makes the final decision. In this case budgetary audit participates as an assisting authority which helps the Parliament in the decision making process. Its work consists of gathering and preparing materials with the report necessary for Parliament to make a decision on the work of executive bodies.

Budget audit is conducted through certain phases and three most important ones are preparation, middle and final phase.

During preparation, it is the task of budget audit to gather data necessary for making the necessary opinion. This material most often consists of results and statements of budget controllers, financial statements on certain portfolio and other explanations by the manager.

Budget audit relies on data given by budget controllers during their work, taking into consideration a control risk (Damnjanović, Mihajlović, 2012). Every portfolio makes their financial statements individually, whereas the financial portfolio makes the final financial statement, where it shows and explains the financial operations from the related budget year. Explanations made by the manager generally relate to overdraft or explanations of certain parts of financial statements.

Budget audit processes the gathered material, taking into consideration control risk and completes its report with a certain opinion. An example of this report is delivered to the Parliament and the executive government. Budget audit should usually deliver recommendations on budget financial reforms to the Parliament in the attachment of the report.

Middle phase begins when budget audit delivers its report with certain attachments to the Parliament, which then directs it to the Parliamentary Committee who is assigned to study the report and make a document that will serve the plenum as a basis and a starting point for discussion and decisions.

When studying the submitted report, the committee should pay special attention to the following facts: whether there are budget violations, especially in cases when there were controversial interpretations between managers and controllers, reasons and motives that managers gave when justifying budget violations and whether budgeting was regular i.e. expedient.

7 Lower managers and accountants only work within the limits of jurisdictions delegated by head manager. 
Third i.e. final phase of budget audit is completed in Parliament's plenum i.e. Parliament. Auditor General states the significant parts of the report made by auditors in the Parliament, which serves as a basis for studying, discussion and decision-making. In this part of work by Parliament, attention is given to basic facts stated in the report. After discussion, Parliament makes the decision that can be a discharge, indemnity or a condemnation.

If budget execution was regular according to legal norms, the Parliament gives the executive government a discharge, if there were budget violations during its execution (overruns etc.) but the executive government manages to convince the Parliament that those violations were justified, i.e. useful for state interests, the Parliament will give an indemnity and if the Parliament finds that budgeting wasn't purposeful it will determine responsibility of the executive government.

In most countries, the Parliament adopts the financial statement with the aforementioned decision, while in some it only discusses it without its adoption.

From the said it can be concluded that efficiency of budget audit mainly depends on whether the question of head managers' responsibility is regulated, if it exists budget audit will be effective, otherwise it will be ineffective.

\section{Conclusion}

Head managers should be held responsible for their procedures in budgeting with: criminal responsibility, civil liability and political responsibility. For civil and criminal responsibility there are courts and for political responsibility the Parliament has jurisdiction, whose conviction consists of a declaration of mistrust. Theoretically head managers could be held responsible through civil and political responsibility and eventually criminal. Past practice showed that most often there is only political responsibility.

There are multiple reasons that confirm the statement that head managers who violated budget discipline were not held responsible through civil or criminal responsibility.

Budget overruns are undoubtedly legal violations, but those violations can be very useful, not to say necessary. If head managers were to answer for budget violations, then they would start avoiding orders that are according to state interests, making such actions a violation to the budgetary law. It is for this reason that many experts do not accept positions of head managers.

Considering violations made regarding purpose of the budget, those should be dealt by the ones who adopted it. Head managers will elaborate on all budget violations to the Parliament. According to their justification, the Parliament will adopt them, give the executive government indemnity or announce a condemnation. This represents the only possible sanction. This confirms that there are no precautions, which will save the state from damages if public finances are in the wrong hands and a million political condemnations do not contain any compensation for damages.

Timely writing of financial statements is a condition of efficiency of budget audit. If financial statements do not arrive in time, budget audit is without a subject, the Parliament 
does not have interest to study budget procedures that happened a long time ago and there is no effect in publicly condemning people who abandoned their positions as head managers many years ago.

Finally, it is necessary to mention the usefulness of budget audit depends on whether the Parliament is guided by interests of public finance or by its political party when making decisions. It is a necessity for the Parliament to be guided by interests of public finance when making their decisions.

It is very harmful to public finances if the executive government is certain in its Parliamentary majority and finds it reassuring when performing budget violations even when they are not necessary. On the other hand it is harmful if the executive government is not able to perform those deviations, which would be useful due to lack of certainty in Parliamentary majority.

\section{Literature}

1. Allen, R., Tommasi, D. (2001): Managing Public Expenditure, OECD, Paris, France

2. Andrić M., Krsmanović, B., Čalija, N., Kulina, D. (2007): Revizija javnog sektora, Ekonomski fakultet, Subotica.

3. Andžić, R. (2013): Penzijsko osiguranje u Srbiji-statistički aspekt, Oditor, No. 6, pp. 11-25.

4. Bojić, M. (2009): Revizija javnog sektora, magistarska teza, Fakultet za menadžment „Braća Karić“, Beograd

5. Damnjanović, R., Mihajlović, M. (2012): Komparativni prikaz različitih koncepcija planiranja i pripreme budžeta, Oditor, No. 3, pp. 26-31.

6. Filipova, L. (2015): Competence of the State audit office of the Republic of Macedonia and review of the INTOSAI standards and reports of the State Audit, Journal of Process Management, Vol. 3, No. 3, pp. 61-68.

7. Gavrić, S. (2015): Standardi revizije, Oditor, No. 11, pp. 17-24.

8. IFAC (2000): Governmental Financial Reporting, Accounting Issues and Practices, Study 11. New York

9. Lončar, Z. (2012): Kontrola uprave od strane državne revizorske institucije, Teme, Vol. 36, No. 3, pp. 1301-1318.

10. Milojević, I. (2008): Osnove budžetskog računovodstva, Univerzitet BK, Beograd

11. OECD (2000): Accrual Accounting and Budgeting Practices in Member Countries, Overview, PUMA/SBP (2000) 11. Official document presented at the International Accrual Accounting and Budgeting Symposium, 13-14 November 2000. Paris

12. Pollitt, C. (2003): Performance audit in Western Europe: trends and choices, Critical Perspectives on Accounting, Vol. 14, No. 1-2, pp. 157-170.

13. Raičević, B. (2005): Javne finansije, Ekonomski fakultet, Beograd

14. Stanojević, Lj., Trivan, D., Bakreski, O. (2016): Kvantitativna analiza ocene rizika revidiranja, Oditor, Vol. 2, No. 3, pp. 21-38.

EP 2018 (65) 1 (337-348) 
15. Šuput, J. (2014): Državna revizorska institucija i prevencija kriminaliteta belog okovratnika u javnom sektoru, Nauka, bezbednost, policija, Vol. 17, No. 1, pp. 153-163.

16. Vijayakumar, A. N., Nagaraja, N. (2012): Internal Control Systems: Effectiveness of Internal Audit in Risk Management at Public Sector Enterprises, BVIMR Management edge, Vol. 5, No. 1, pp. 1-8.

17. www.INTOSAI.org - Lima Declaration

\title{
RAČUNOVODSTVENI ASPEKTI BUDŽETSKE REVIZIJE
}

\author{
Ivan Milojevičc ${ }^{8}$ Rosa Andžič ${ }^{9}$, Vladan Vladisavljevićc ${ }^{10}$
}

\section{Sažetak}

Izvršenje budžeta, kao osnovnog instrumenta državnog finansiranja, donedavno je bilo praćeno isključivo postojećim sistemom državnih administrativnih kontrola. Danas kao poseban vid političke kontrole javlja se budžetska revizija, koja u svom radu treba da doprinese što pravilnijem i celishodnijem izvršenju budžeta. Ona je danas uslov sine qua non, dakle neminovan uslov za zdrave javne finansije.

Ključne reči: računovodstvo, budžet, revizija, finansije.

8 Redovni profesor, dr Ivan Milojević, Univerzitet odbrane, Vojna akademija, Katedra za finansije, Ulica Pavla Jurišića Šturma br. 33, 11000 Beograd, Srbija, E-mail: drimilojevic@gmail.com,

9 Redovni profesor, dr Rosa Andžić, Visoka škola za menadžment i ekonomiju, Karađorđeva ulica br. 52, 34000 Kragujevac, Srbija, E-mail: rosa.andzic@vsem.edu.rs

10 Master, Vladan Vladisavljević, Asistent, Univerzitet odbrane, Vojna akademija, Katedra za finansije, Ulica Pavla Jurišića Šturma br. 33, 11000 Beograd, Srbija, E-mail: vlada91@gmail.com 